\title{
Social representations of nursing students on the rights of health users
}

\author{
Representações sociais de estudantes de enfermagem sobre os direitos dos usuários da saúde \\ Representaciones Sociales de estudiantes de enfermería sobre los derechos de los usuarios de la salud
}

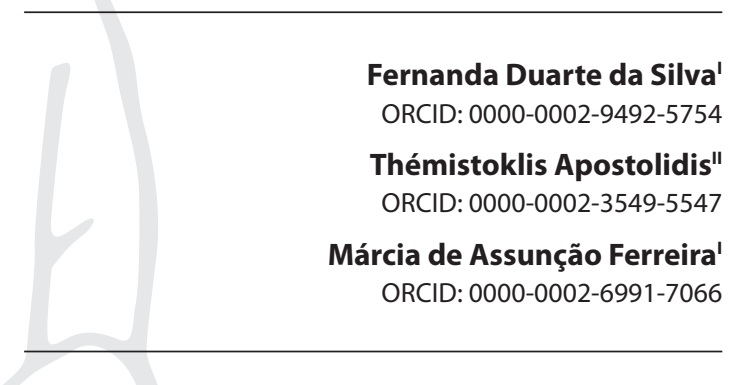

'Universidade Federal do Rio de Janeiro. Rio de Janeiro, Rio de Janeiro, Brazil.

"Aix-Marseille Université, Laboratoire de Psychologie Sociale. Aix-en-Provence, France.

How to cite this article:

Silva FD, Apostolidis T, Ferreira MA. Social representations of nursing students on the rights of health users. Rev Bras Enferm. 2020;73(6):e20190510. doi: http://dx.doi.org/10.1590/0034-7167-2019-0510

Corresponding author:

Fernanda Duarte da Silva

E-mail: fernandaantonioduart@yahoo.com

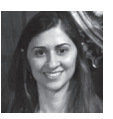

EDITOR IN CHIEF: Antonio José De Almeida Filho ASSOCIATE EDITOR: Hugo Fernandes

Submission: 09-30-2019

Approval: 05-05-2020

\begin{abstract}
Objective: To identify the social representations of undergraduate nursing students in the third and eighth term of the course on the rights of health users. Methods: Qualitative research using the framework of the structural approach to the Theory of Social Representations. A total of 92 students participated. The free evocation technique was used and data was processed in the EVOC software. Results: In the social representations of the third term students, words related to health policies were not observed, but there is an evaluation of the service in the institutions. Among the eighth-grade students, the concepts that support the policies of the Unified Health System are evident. Final considerations: There is a consolidation of the students' knowledge throughout the course, with a more elaborated knowledge about the users' right, supported by principles of the SUS. Undergraduate education is an important space for discussing the construction and exercise of citizenship, including the right to health.
\end{abstract}

Descriptors: Nursing; Students, Nursing; Psychology, Social; Patient Rights; Ethics, Nursing.

\section{RESUMO}

Objetivo: Identificar as representações sociais de estudantes de graduação em enfermagem do terceiro e oitavo período do curso, sobre os direitos dos usuários da saúde. Método: Pesquisa qualitativa com referencial da abordagem estrutural da Teoria das Representações Sociais. Participaram 92 estudantes. Utilizou-se a técnica de evocações livres, sendo os dados processados pelo software EVOC. Resultados: Nas representações sociais dos estudantes do terceiro período, não se observam termos relacionados às políticas de saúde, mas há avaliação sobre o atendimento nas instituições. Nas dos estudantes do oitavo, evidenciam-se conceitos sustentadores de políticas do Sistema Único de Saúde. Considerações finais: Nas representações sociais dos estudantes do terceiro período, não se observam termos relacionados às políticas de saúde, mas há avaliação sobre o atendimento nas instituições. Nas dos estudantes do oitavo, evidenciam-se conceitos sustentadores de políticas do Sistema Único de Saúde.

Descritores: Enfermagem; Estudantes de Enfermagem; Psicologia Social; Direitos do Paciente; Ética em Enfermagem.

\section{RESUMEN}

Objetivo: Identificar las representaciones sociales de los estudiantes universitarios de enfermería del tercer y octavo período del curso, sobre los derechos de los usuarios de la salud. Métodos: Se trata de una investigación cualitativa con referencial del enfoque estructural de la Teoría de las Representaciones Sociales, realizada entre 92 estudiantes mediante la técnica de evocación libre y el software EVOC para el procesamiento de los datos. Resultados: En las representaciones sociales de los estudiantes del tercer período no se observan términos relacionados con las políticas de salud, aunque existe una evaluación de la atención de las instituciones. En los estudiantes del octavo, hay conceptos que demuestran apoyo a las políticas del Sistema Único de Salud. Consideraciones finales: A lo largo del curso se produce una reificación del conocimiento de los estudiantes, con un saber elaborado sobre el derecho de los usuarios y basado en los principios del SUS. La educación universitaria es un espacio importante de problematización para la construcción de la ciudadanía y su ejercicio, incluyendo el derecho a la salud. Descriptores: Enfermería, Estudiantes de Enfermería, Psicología Social; Derechos del Paciente. Ética en Enfermería. 


\section{INTRODUCTION}

In 1948, in the Universal Declaration of Human Rights (UDHR), the United Nations (UN) recognized the right to health as an inalienable, fundamental right of every human being and as a social value. Therefore, the UN recommends that countries provide the conditions for people to enjoy this right and guarantee access to quality health care.

In Brazil, the Federal Constitution enacted in 1988 understands health as one of the social rights inherent to citizenship. Health is recognized as a right of all citizens and a duty of the government. The right to health is provided through economic and social policies and an Unified Health System (SUS) that is universal, public, participatory, decentralized and comprehensive ${ }^{(1)}$.

In line with the UDHR and the Constitution of 1988, Brazil releases the Letter of Rights of the Healthcare User, which addresses universal and equal access to actions and services for health promotion, protection and recovery, with humane and hospitable care, free from any discrimination and in compliance with SUS guidelines ${ }^{(2)}$.

There are legal documents that guarantee the right to health. In this sense, it is a complex problem if citizens do not have their right respected and must resort to the Law and to the court. The judicialization of health is a growing process, with incessant struggles with lawsuits against the government. According to the National Council of Justice of Brazil, in 2011, there were more than 240 thousand health lawsuits against the government, with more than 25 thousand of those in the state of Rio de Janeiro. These legal procedures have been increasing at an accelerated and constant rhythm; however, their resolution by the judiciary system does not happen at the same pace, so SUS users have to face long lines in this sphere of power as well. As a consequence, many deaths occur before the patient can access their right to care $^{(3-4)}$.

According to national and international nursing codes of ethics, the nursing profession includes respect for human rights, and it is the professional's duty to inform users of their rights. Therefore, the principles of the profession act in defense of the universal right to health ${ }^{(5-6)}$.

The nursing profession, as a science and as the art of caring and helping people, is a practice inserted in the world of work and, therefore, it should be understood as a social practice by undergraduate nursing students. In this sense, it is essential that, during their training, undergraduate students develop the knowledge that will prepare them to work in the SUS, recognizing it as a public, equitable and democratic system, and to face the challenges of the health area ${ }^{(7-8)}$.

\section{OBJECTIVE}

This work aims to identify the social representations (SR) of undergraduate nursing students in the third and eighth term of the course on the rights of health users.

\section{METHODS}

\section{Ethical aspects}

The project was submitted to the Research Ethics Committee of the institution hosting the research, through the Plataforma
Brasil. All participants were asked to sign the informed consent form, in compliance with the requirements established in Resolution No. 466/12 of the National Health Council.

\section{Theoretical and methodological framework and type of study}

This is an explanatory research, using the Social Representations Theory (SRT) and its structural approach as framework. SR are a set of information, beliefs, opinions, and attitudes in relation to a given social object. There are four functions of SR: the knowledge function, which allows understanding and explaining reality; the identity function, which defines the identity and protects the specificity of each group; the orientation function, which guides behavior and practice; and the justificatory function, which justifies decisions and behavior ${ }^{(9)}$.

From the perspective of the structural approach, SR are composed of a central and a peripheral system, each with its own characteristics and functions and complementary to one another. Peripheral elements are organized around the central core, which has the most accessible, most alive and most concrete components. They are responsible for three main functions: implementation, regulation and defense. In the peripheral system, there may be contradictions, which are more associated with individual characteristics and immediate context ${ }^{(10)}$.

SR are organized around a central core, which can have two dimensions. The first one is the functional dimension, which has an operational purpose and is composed of elements essential to the accomplishment of the task. The second one is the normative dimension, related to socio-affective, social or ideological dimensions ${ }^{(10)}$.

It is understood that the object of this research is part of the daily life of nursing students and involves knowledge, affections, attitudes and images of practices and of nursing professionals, which may or may not meet the right to healthcare; therefore, it is the object of SR. Thus, the use of the structural approach in this study allowed the analysis of the SR of two groups of undergraduate students, from the third and the eighth term of the course. There SR may be different if the contents of the respective central cores are different ${ }^{(10)}$.

\section{Methodological procedures}

\section{Study setting}

The study was carried out in a public nursing school in Rio de Janeiro. This institution was chosen as study site for two reasons: a previous research was conducted with undergraduate nursing students at this institution, and the results led to the assumption that the rights of health users are an object of SR for nursing students; the curriculum of this institution includes contact with healthcare users since the first term of the course, which provides practical experiences of care at the beginning and at the end of training.

\section{Data source}

The research was carried out with undergraduate students from the third and eighth semester of the course, that is, at the end of the first stage of the curriculum, when students approach health as a lifestyle and assist supposedly healthy people in their life contexts 
(schools and workspaces), and at the end of the course. Adding the third and eighth terms, the population consisted of 100 students. Inclusion criteria were: age of 18 or above, active enrollment and attendance at classes. Exclusion criteria were: students without regular attendance, students who were absent from activities during the data collection period and students who were transferred from other institutions. After applying these criteria, a sample of 92 students was obtained, of which 49 were from the third term of the course and 43 from the eighth. According to the literature, there is no minimum number of participants, but around 100 participants are recommended in order to have reliable results. (11). In this research, the sample size was sufficient to outline the empirical and theoretical analysis and to achieve the objectives.

\section{Data collection and organization}

The technique of free evocations is a projective test, whose objective is to locate the areas of blocking and repression of thought. It captures the apprehension of mental projections in a spontaneous way and may unveil content that does not appear in discursive productions. Evocations were collected using a printed instrument, applied collectively to each class in both terms studied. Students were asked to write up to five words or expressions that came to mind, after citing the inducive term 'rights of health users.'Then, the participants were asked to organize responses in order of importance, from the most to the least important. The maximum of five words was chosen because after the seventh word there is a decline in the speed of responses, compromising the spontaneous and natural character of the technique ${ }^{(10-11)}$.

\section{Data analysis}

The data were processed in the EVOC Software (Ensemble de programmes permettant l'analyse des evocations), 2003 version, developed by Vergès. This software allows the organization of the evocations produced according to their frequencies and the order of evocation. The intersection between the frequency and the hierarchical order of the evocations allows the construction of a four-box chart, which depicts the content and structure of the SR. It has four quadrants; the most significant terms and the possible central core of the SR are located in the upper left quadrant. The words located in the upper right and lower left quadrant are the elements of the 1st periphery and the elements of contrast, respectively. The terms in the lower right quadrant are the most peripheral elements of the representation, called the 2 nd periphery ${ }^{(10)}$.

The evocations and expressions were typed in the Word software, in the same way as they were written by the participants and based on the natural order of the evocations; then, the words and terms were corrected. Finally, a dictionary for the standardization of evocations was created, with the objective of preserving the semantic content expressed by the participants ${ }^{(10)}$.

\section{RESULTS}

The evocations of students at the beginning of the undergraduate nursing course constituted a single corpus for analysis, consisting of 401 words, of which 76 are different from each other. To define the elements of the central core and the peripheral system, the Average Order of Evocation (AOE) was calculated. The AOE is calculated by a weighted average, assigning a numerical value for each evocation according to the order of appearance; then, the sum is divided by the total number of times the word was cited. In this corpus, the Average Order of Evocation was 3. In this analysis, the minimum frequency was 6 and the mid frequency was 11, as shown in Chart 1.

Chart 1 - Distribution of elements according to frequency of evocation and Average Order of Evocation by students of the 3rd term of the undergraduate nursing course, Rio de Janeiro, Rio de Janeiro, Brazil, 2019

\begin{tabular}{|c|l|c|c|l|c|c|}
\hline \multicolumn{3}{|c|}{ RANG < 3 } & \multicolumn{3}{c|}{ RANG > 3 } \\
\hline $\begin{array}{c}\text { Mid } \\
\text { frequency }\end{array}$ & Evocations & Freq. & AOE & Evocations & Freq. & AOE \\
\hline \multirow{4}{*}{11} & Values & 20 & 2.88 & Neglect & 12 & 3.16 \\
\cline { 2 - 8 } & Hospital & 14 & 2.64 & Professionals & 11 & 4.09 \\
\cline { 2 - 8 } & Good service & 13 & 2.25 & & & \\
\hline \multirow{4}{*}{11} & Quality & 9 & 2.87 & SUS & 10 & 3.20 \\
\cline { 2 - 8 } & Precariousness & 9 & 2.66 & Poor service & 9 & 4.00 \\
\cline { 2 - 8 } & Laws & 8 & 2.22 & Good & 7 & 3.14 \\
\cline { 2 - 8 } & & & & Humanization & 7 & 3.50 \\
\hline
\end{tabular}

Note: $A O E=$ Average Order of Evocation.

The upper left quadrant is the possible central core of SR; it contains the words that are highlighted in the discourses and that were the most cited by the students at the beginning of the undergraduate nursing course. Thus, the possible central core consists of the following evocations: values (20), hospital (14) and good service (13). The peripheral elements are located around the central core and divided into first periphery, in the upper right quadrant, and second periphery, in the lower right quadrant.

The first periphery contains the words cited with a high frequency, greater than or equal to 11 , and high $\mathrm{AOE}$. It contains the following evocations: neglect (12) and professionals (11). The second periphery has evocations with low frequency and high AOE: SUS (10), poor service (9), good (7) and humanization (7). These peripheral elements represent an approximation to the reality of the subjects. The contrasting elements are located in the lower left quadrant: quality (9), precariousness (9) and laws (8). These contrasting elements indicate that there are secondary representations by a group of subjects, different from the representations in the studied group.

The evocations of students in the eighth term of the undergraduate nursing course constituted a single corpus for analysis, consisting of 451 words, of which 79 are different from each other. To define the elements of the central core and the peripheral system, the Average Order of Evocations (AOE) was calculated, which in this corpus was 3 . In this analysis, the minimum frequency was 5 and the mid frequency was 11, as shown in Chart 2. The upper left quadrant is the possible central core of SR; it contains the words that are highlighted in the discourses and that were the most cited by the students, consisting of the following evocations: humanization (16), good service (16) and access (14). The peripheral elements, which are close to the reality of the subjects, are located around the central core and divided into first periphery and second periphery. 
Chart 2 - Distribution of elements according to frequency of evocation and Average Order of Evocation by students of the 8th term of the undergraduate nursing course, Rio de Janeiro, Rio de Janeiro, Brazil, 2019

\begin{tabular}{|c|l|c|c|l|c|c|}
\hline \multicolumn{3}{|c}{ RANG < 3} & \multicolumn{3}{c|}{ RANG $>\mathbf{3}$} \\
\hline $\begin{array}{c}\text { Mid } \\
\text { frequency }\end{array}$ & Evocations & Freq. & AOE & Evocations & Freq. & AOE \\
\hline \multirow{4}{*}{11} & Good service & 16 & 2.42 & Values & 16 & 3.36 \\
\cline { 2 - 7 } & Humanization & 16 & 2.60 & Equality & 12 & 3.25 \\
\cline { 2 - 7 } & Access & 14 & 2.43 & Hospital & 11 & 3.41 \\
\hline \multirow{4}{*}{11} & Laws & 10 & 2.50 & Quality & 8 & 4.40 \\
\cline { 2 - 7 } & SUS & 8 & 2.80 & Knowledge & 8 & 3.12 \\
\cline { 2 - 7 } & Primary care & 5 & 2.50 & Neglect & 6 & 3.20 \\
\cline { 2 - 7 } & & & & Training & 5 & 3.00 \\
\cline { 2 - 7 } & & & & Care & 5 & 3.50 \\
\hline
\end{tabular}

Note: $A O E=$ Average Order of Evocation.

Chart 3 - Distribution of evocations according to the frequency and location of the order of evocations by students from the 3rd and 8th terms of the undergraduate nursing course, Rio de Janeiro, Rio de Janeiro, Brazil, 2019

\begin{tabular}{|c|c|c|}
\hline \multicolumn{3}{|c|}{ Evocations present in both terms of the Nursing course } \\
\hline Evocation & $\begin{array}{c}\mathbf{3}^{\text {rd }} \text { term }- \text { frequency } \\
\text { and location }\end{array}$ & $\begin{array}{c}\mathbf{8}^{\text {th }} \text { term } \text { - frequency } \\
\text { and location }\end{array}$ \\
\hline Hospital & 14 (central) & 11 (1st periphery) \\
\hline Values & 20 (central) & $16\left(1^{\text {st periphery) }}\right.$ \\
\hline Quality & 9 (contrast) & $8\left(2^{\text {nd }}\right.$ periphery) \\
\hline Laws & 8 (contrast) & 10 (contrast) \\
\hline Neglect & 12 (1 $1^{\text {st }}$ periphery) & 6 (contrast) \\
\hline SUS & 10 (2 $2^{\text {nd }}$ periphery) & 8 (contrast) \\
\hline Good service & 13 (central) & 16 (central) \\
\hline Humanization & $7\left(2^{\text {nd }}\right.$ periphery) & 16 (central) \\
\hline
\end{tabular}

Chart 4 - Distribution of evocations exclusive to each period, frequency and location of the order of evocation by students from the 3rd and 8th terms of the nursing undergraduate course, Rio de Janeiro, Rio de Janeiro, Brazil, 2019

\begin{tabular}{|c|c|c|c|}
\hline \multicolumn{4}{|c|}{ Evocations exclusive to each term of the nursing course } \\
\hline $3^{\text {rd }}$ term & $\begin{array}{l}\text { Frequency } \\
\text { and location }\end{array}$ & $8^{\text {th }}$ term & $\begin{array}{l}\text { Frequency } \\
\text { and location }\end{array}$ \\
\hline Precariousness & 9 (contrast) & Access & 14 (central) \\
\hline Professionals & 11 (1a periferia) & Atenção básica & 5 (contraste) \\
\hline Poor service & $11\left(1^{\text {st }}\right.$ periphery $)$ & lgualdade & 12 (2aperiferia) \\
\hline 9 ( $2^{\text {nd }}$ periphery) & Primary care & Capacitação & 8 (2a periferia) \\
\hline Equality & 5 (contrast) & Conhecimento & 5 ( $2^{\mathrm{a}}$ periferia) \\
\hline 12 ( $2^{\text {nd }}$ periphery) & & Cuidado & 5 (2a periferia) \\
\hline \multirow[t]{3}{*}{ Good } & 7 ( $2^{\text {nd }}$ periphery $)$ & Training & 8 ( $2^{\text {nd }}$ periphery $)$ \\
\hline & & Knowledge & 5 ( $2^{\text {nd }}$ periphery) \\
\hline & & Care & 5 ( $2^{\text {nd }}$ periphery) \\
\hline
\end{tabular}

The first periphery contains the words cited with a high frequency, greater than or equal to 11, and high $\mathrm{AOE}$, namely: values (16), equality (12), hospital (11). On the other hand, the second periphery contains evocations with low frequency and high AOE: quality (8), knowledge (8), neglect (6), training (5) and care (5). The contrasting elements indicate that there are secondary representations by a group of subjects. These elements, located in the lower left quadrant, are: laws (10), SUS (8) and primary care (5).

The analysis of the structural approach to the SR of both groups, shown in the four-box charts, showed similarities and differences between the elements of the SR of the students at the beginning and end of the undergraduate nursing course, as shown in the Chart 3 and 4.

The SR of students starting the undergraduate nursing course have in their evaluative dimension more negative elements in relation to the rights of health users, such as precariousness and poor service, as opposed to good and good service. The students who are leaving the course have SR with more positive elements, as there is only one negative evocation represented by the word neglect. On the other hand, for students at the beginning of the course, elements of polarity, sometimes positive, sometimes negative, appear in the peripheries and in the contrast elements, as shown in Chart 4.

Chart 3 shows that in the central core of social representations of students in the third term there are no aspects directly related to specific terms of health policies, but there are meanings related to being well looked after in a health institution, in this case, the hospital, through the terms "values", "good service" and "hospital". In the group of undergraduate students, specific terms such as "good service", "humanization" and "access" appear; the last two are concepts that support SUS policies, which aim to provide a good service to the population.

\section{DISCUSSION}

For a better understanding of the meaning of the words cited by the group of students in the third term, evocations were grouped in four dimensions: conceptual, individual, evaluative and spatial. The central core gives meaning to the SR. In this core, the word with the highest number of evocations was "values", with the other two tied ("hospital" and "good service"). Thus, the word "values" is characterized as a prominent element in the analysis of the SR of students at the beginning of the course. For this group, what gives meaning to the rights of health users is a matter of value on the part of professionals.

It is worth noting that, since each individual has their own values, which can be different from those of others in the same group or in different groups, such values can influence practices and relationships with others. Therefore, it is necessary to understand that the dimension that addresses the rights of health users is a matter of value, because, if these rights are not understood within the set of ethical and social values of citizens, there can be ethical and legal implications in context of health as a right of all citizens and a duty of the government ${ }^{(12)}$. Users' rights must be guaranteed, regardless of personal values. Thus, the relationship between the rights of health users and values can only encompass the individual dimension of SR for this group, if the latter is not understood in the context of ethics and citizenship, rights and duties.

It is worth noting that the words in the first periphery are "professional" and "neglect", which complement the idea in the central core. The evocation "laws" appeared in the discourse; however, it appears in the contrast zone, in a tie with the evocations words "quality" and "precariousness". These terms that are within the 
evaluative dimension evoke the idea of opposition, as they are sometimes positive, sometimes negative, such as "good" and "good service" as opposed to"neglect", "bad service" and "precariousness". This conflict in the evaluation of health services in Brazil is found especially when it comes to the evaluation of the SUS ${ }^{(13-18)}$.

In the conceptual dimension, the term "laws" also appeared. This is not exactly a surprise, since, when thinking about people's rights, the idea of a law that guarantees these rights is promptly evoked in the social imaginary based on common sense. The Brazilian legal system was influenced by the legal conceptions of Romano-Germanic law, due to the fact that Brazil was colonized by Portugal, which followed/follows this tradition ${ }^{(19)}$. Therefore, the Brazilian legal system has an organization system similar to that of France and Germany, with the construction of the legal system based on the code. Therefore, the Brazilian legal the system has the law as its primary source - it expresses the idea of codified and positive law ${ }^{(19)}$. This explains the origin of the common idea of using Laws to announce or defend rights and justifies the presence of this idea in the social imaginary and in the representations of nursing students about users' right to health.

In Brazil, the rights of health users include the creation of the SUS as recognition that health is a fundamental human right and that the government must provide the conditions necessary for its full exercise. Therefore, it is possible to understand the evocation of the term "law", since thinking about the rights of health users implies understanding and recognizing that health is a right guaranteed by law and is the function of the SUS - law 8.080, September 19, 1990 (4,20-21).

The word hospital appears in the central core of the SR of this group. This represents the spatial dimension of users' rights for students at the beginning of the course. This result is in line with other studies on the SR of undergraduate nursing students and health users, which also show an association of health, the rights of health users and the SUS with the hospital environment, demonstrating the predominance of a biomedical character of health ${ }^{(11,14-16)}$.

For students at the beginning of the undergraduate nursing course, SR are marked by an evaluative dimension, composed of negative and positive elements, as can be observed by the following evocations: "precariousness", in the elements of contrast; "neglect" and "poor service" in the periphery; "good service" in the central core; and "good" in the periphery. These antagonistic elements are also present in the imaginary and in social representations about the care offered in SUS, as demonstrated in a study that shows a representation under construction, informing that the system hinders the access to comprehensive care ${ }^{(22)}$.

The probable central core of the SR of health users' rights for this group is associated with good care, which comprises the evaluative dimension. However, the reality experienced by the group is of a poor service, since this term appeared in the second periphery, which represents an approximation to the reality of the subjects. The analysis of the structure of the SR shows that the entire structure is related to the service: in the central nucleus, the evocation is "good service"; in the first periphery, "neglect"; in the second periphery, "poor service"; and, in the area of contrast, "quality" and "precariousness". However, the most important word in the analysis, that is, the work with the highest number of evocations in the central core, is "values", precisely because this element may be able to influence a service, whether in a good or a bad way. Other terms such as "hospital" and "SUS" also support this discourse, since they can be understood in the context of health-disease representations, which are still influenced by the biomedical model of actions and services in public health ${ }^{(23)}$. This justifies the evocation of the word "hospital", which is a common place to treat diseases, but generally referred to as a health treatment environment. In this sense, recognizing the right to health care means recognizing that the care must be good and must happen somewhere, such as the hospital, within the scope of the Unified Health System (second periphery).

The idea of humanization adds a good evaluation to health care, as evidenced in the speeches of nursing students. As done in the analysis with students in the third term, the evocations of the eighth term students were grouped into the four dimensions already mentioned in order to better understand their meaning: conceptual, individual, evaluative and spatial. In this group, the word with the highest number of evocations was humanization (16), followed by good service (16) and access (14), with a good balance between them.

Addressing humanization in the health area brings up the discussion about dehumanization. The imaginary about this object appears as a necessity in an environment in which the opposite occurs - dehumanization. In this perspective, in view of the contrast in health services, humanization refers to being a human, having feelings that value humanity and recognizing the other as a subject with dignity. The association of this term with the rights of health users indicates that the right to health is still regarded in the field of interpersonal relationships and associated with the ethics of health care and nursing care. This is evidenced in studies addressing the SR of humanization by undergraduate nursing students, health professionals and users ${ }^{(8,24-25)}$. This topic represents a challenge for the comprehension of the National Humanization Policy, which has the objective of reaffirming SUS principles and guidelines as equitable and universal public policies ${ }^{(26)}$.

Access was a term that also appeared in the central core of the SR of the group and it is in accordance with the first of the six basic principles established in the Letter of Rights of the Healthcare User. These principles ensure the basic right to decent access into health systems, whether public or private, highlighting that every citizen has the right to an orderly and organized access to health systems in Brazil. It should be noted that access, as a mean of guaranteeing the rights of health users, is a priority and a fundamental element not only in the Brazilian Letter of Rights of the Healthcare User: other countries also have devices that guarantee access: in the form of law in Scotland; as a statute in Kenya; as a letter in Australia and in France, where access to health services is guaranteed for all French citizens ${ }^{(27)}$.

The conceptual dimension is expressed in the term "SUS". This term, along with "primary care" and "laws", appeared in the contrast zone, leading to the understanding that the group may have secondary representations with these terms. As an object of representation, SUS is associated with elements of opposition, sometimes positive, sometimes negative, related to precariousness, access and care provided to users in public health services ${ }^{(22)}$.

The term neglect appeared in the second periphery and is included in the evaluative dimension of the SR of health users' rights for this group. Neglect in the care provided to health users 
in the SUS almost always appears in the population's imaginary. This image is highly influenced by the media, which portrays chaos, long lines, delay in services and an image of a failed health system. However, this imaginary is criticized by several health professionals, considering that, even though these problems are part of the reality of the SUS, situations that convey the positive image of a SUS that works are rarely presented. When this positive image appears in the media, it is usually through the discourse of health users about their successful experiences in health practices. ${ }^{(15-18)}$.

Indeed, in the scope of the SUS, there are proposals for changes in health practices involving the social actors who perform these practices on a daily basis. These proposals include chatting circles with health professionals, users and managers on topics such as successful practices and problems of the SUS, so that the challenges of the public health service for the Brazilian population can be dealt with ${ }^{(16-17)}$.

The spatial dimension was represented by the evocations "hospital" and "primary care". The influence of the hospital-centered model on the representations by professionals and by the Brazilian population is undeniable, since hospitals were and still are the physical spaces that represent the health system. However, it is worth noting that public and governmental policies are increasingly working towards the recognition of a primary health care model with emphasis on the expansion of family health strategies throughout the Brazilian territory.

The Family Health Strategy (FHS) can have a key role in the transformation of society by enabling individuals and the community to develop skills to participate in society life. In this direction, skills and reflective thoughts are developed and help individuals to leave a situation of resignation and accommodation in relation to the reality experienced. The change in the care paradigm involves changing from a curative approach into a preventive approach with focus health promotion, from unilateral into intersectoral actions, and from exclusion into universality. Thus, the FHS can become a key instrument for the empowerment of the population ${ }^{(15)}$.

For this group, the individual dimension is associated with the values of health professionals. It is important to note that the other evocations in the individual dimension are in the second periphery, establishing a relationship with the reality of the subjects. Therefore, knowledge, training and care are part of the reality of the group. This result shows that the university, through training, has a prominent role in the construction of students' knowledge on the subject and is a favorable space for reflection, debate and discussion on the theme, emphasizing the importance of the actions taken by health professionals with the objective of contributing to the guarantee and recognition of the rights of health users.

Regarding the role and the performance of the team and of the profession, the following elements do not appear in the evocations of students at the end of the undergraduate nursing course: "training", "knowledge" and "care". It is considered that, for this group, such elements are important to guarantee and recognize the rights of health users, associating the profession to the science of nursing through the words "knowledge" and "care". Therefore, for the first group, the role of the professional has a more practical, objective and instrumental dimension, and may be associated with the team and with its presence. The students at the end of the course have a perspective that expands to include the need for knowledge and for specific training to care, bringing to discussion the importance of formal education to act on the rights of health users.

Graduating students of the undergraduate course associate users' rights to access with primary care and equality, which are elements that make up the SUS. For this group of students, the SUS appears as a contrasting element, demonstrating a possible secondary representation. For students in the third term of the course, the evocation "SUS" appears in the second periphery, where it is associated with reality. It is observed that graduating students cite equality, which is an important concept in the field of public health, since assuming that the other is equal in the sphere of health means recognizing that health is a fundamental human right that should be offered to all citizens. These premises have guided social movements that fought for the creation of the SUS as a unified Brazilian public health system, offered to all citizens without any discrimination by race, color, gender or social class ${ }^{(1)}$.

Addressing the law in the field of health considering the principle of equality is to guarantee access to the entire Brazilian population, recognizing the role of primary care as an important gateway to health promotion and disease prevention for the Brazilian population, involving a challenging interdisciplinary field. The training of health professionals, including nurses, has a fundamental role in the dissemination and consolidation of knowledge about users' rights to health. In this direction, the results presented so far show that this role has been fulfilled, since the graduating students showed a more concrete knowledge than the students of the third term of the undergraduate course. The knowledge of graduating students is closer to scientific knowledge, as shown in the evocations "knowledge", "training" and "care", in addition to the elements that make up the SUS, such as "access", "primary care" and "equality".

It is observed that the SR are influenced by the conditions of production. In this sense, the students participating in this research experienced, until the third term of the course, practical experiences that led them to provide nursing care to the population, with the objective of developing the concept of health as a lifestyle in schools and transit spaces, such as urban and highway train stations, with actions of primary care and health education. In the third term, students provide care for people outside the health system spaces and have not yet experienced the scenario of the SUS, whether at hospitals or in primary care, nor have they worked with nursing or health teams. Theoretical and practical learning about the SUS and work in primary care starts in the fourth term of the undergraduate course in the university studied. This may also explain why the word "professionals" appears in the evocations of this group instead of a specific professional category, such as doctors and nurses.

It is noted that this group still does not associate the users' right to health with the nursing profession and its professionals. However, it is worth noting that the relationship between the profession and this theme was also not included in the evocations of students at the end of the undergraduate nursing course, despite them having already experienced the SUS health services, both in primary care and in the hospital.

It is observed that the students of the eighth term are inserted in the services in more intense training, in the leadership and supervision of teams; in addition, they have multiple opportunities for debates at the university itself and at events in the area 
of health and nursing, which enables them to add elements to their knowledge and to reflect on the challenges of guaranteeing the rights to health.

According to guidelines of the health area, the profile of its professionals has as fundamental elements the concept of health and the principles and guidelines of the SUS, which are supported by the training of humane general practitioners, with critical and reflective capacity and focus on a teamwork that meets the health needs of the Brazilian population ${ }^{(28)}$. In this case, the representations about the rights of users, linked to the principles of SUS, requires the consolidation of the concept of professionals, considering them as members of work teams. This is a hypothesis to explain why students, especially those from the last term, have cited the word "professional" without distinguishing class, possibly referring to the team member and not to a specific area.

Information is an important dimension of SR. In this sense, the results reveal the consolidation of knowledge of students, who develop, between the third and the eighth term, a more elaborate knowledge about the users' right to health in relation to the SUS ${ }^{(4,29-30)}$.

\section{Study limitations}

A limitation of the study is that data collection was performed only with nursing students from the third and eighth term of only one public education institution in Rio de Janeiro.

\section{Contributions to the Nursing area}

The implications of these results are related to the reassertion of undergraduate nursing education as an important space for discussing the construction and exercise of citizenship, including the right to health, so that students can (re)contextualize knowledge and their actions in the area of health and healthcare.

\section{FINAL CONSIDERATIONS}

The students of the eighth term of the course have exclusive evocations, showing that their SR on the rights of health users include elements of the public policies of the SUS. A common element that stands out is good service, which gives meaning to the SR about the rights of users for students in the third and in the eighth terms of the undergraduate nursing course. Students experience a normative daily life of formal learning, in which they recognize that there is a theoretical framework that aims to ensure that health users are equal, based on the SUS principles of universality, equality and equity in the access to health services, without discrimination of any kind. Theory, ideas and experiences in the context of services are merged and generate the SR of students, especially those who are in the eighth term, finishing the undergraduate nursing course.

\section{FUNDING}

CAPES.

\section{REFERENCES}

1. Paim JS. A Constituição Cidadã e os 25 anos do Sistema Único de Saúde (SUS). Cad Saúde Pública. 2013;29(10):1927-36. doi: 10.1590/0102-311X00099513

2. Ministério da Saúde (BR). Carta dos direitos dos usuários da saúde [Internet]. 3. ed. Brasília: Ministério da Saúde; 2011 [cited 2020 Mar 15]. 28p. Available from: http://bvsms.saude.gov.br/bvs/publicacoes/cartas_direitos_usuarios_saude_3ed.pdf

3. Asensi FD. Direito à saúde: práticas sociais reivindicatórias e sua efetivação. Curitiba: Juruá; 2013. 369p.

4. Ramos RS, Gomes AMT, Oliveira DC, Marques SC, Spindola T, Nogueira VPF. Access the Unified Health System actions and services from the perspective of judicialization. Rev Latino-Am. Enfermagem. 2016;24:e2797. doi: 10.1590/1518-8345.1012.2689

5. Carvalho V. Ética e valores na prática profissional em saúde: considerações filosóficas, pedagógicas e políticas. Rev Esc Enferm USP. 2011;45(spe2):1797-802. doi: 10.1590/S0080-62342011000800028

6. Blondeau D. Valeurs professionnelles, codes de déontologie et modèles relationnels. In: Blondeau D. Éthique et soin infirmiers. Montreal: Les Presses Université de Montreal; 2013. p.127-143.

7. Araújo FP, Sauthier M, Ferreira MA. Social representations of citizenship by inpatients: implications for hospital care. Rev Bras Enferm. 2016;69(4):625-32. doi: 10.1590/0034-7167.2016690402i

8. Freitas FDS, Ferreira MA. Humanization knowledge of undergraduate nursing students. Rev Bras Enferm. 2016;69(2):282-289. doi: 10.1590/0034-7167.2016690211i

9. Morera JAC, Padilha MI, Silva DGV, Sapag J. Aspectos teóricos e metodológicos das representações sociais. Texto Contexto Enferm. 2015;24(4):1157-65. doi: 10.1590/0104-0707201500003440014

10. Abric JC. Les représentations sociales: aspects théoriques. In: Abric JC. Pratiques sociales et représentations. Paris: PUF; 2011. p.15-46.

11. Wachelke J, Wolter R. Critérios de Construção e Relato da Análise Prototípica para Representações Sociais. Psi.: Teor Pesq. 2011;27(4):521-6. doi: 10.1590/S0102-37722011000400017

12. Arreaza ALV. Reconhecimento ético-moral dos direitos emancipatórios para os cidadãos sociais da saúde coletiva. Saúde Debate. 2014;38(101):347-58. doi: 10.5935/0103-1104.20140032

13. Santos El, Gomes AMT, Marques SC, Ramos RS, Silva ACSS, Oliveira FT. Comparative study of representations of professional autonomy produced by first and last-period undergraduate nursing students. Rev Latino-Am Enfermagem. 2017;25:e2927. doi: 10.1590/1518-8345.1919.2927 
14. Scolari GAS, Rissardo LK, Baldissera VDA, Carreira L. Emergency care units and dimensions of accessibility to health care for the elderly. Rev Bras Enferm. 2018;71(Suppl2):811-817. doi: 10.1590/0034-7167-2017-0440

15. Oliveira DC, Cecilio HPM, Gomes AMT, Marques SC, Spíndola T, Pontes APM. The universalization and access to health: consensus and disagreement between professionals and users. Cad Saúde Colet. 2017;25(4):483-490. doi: 10.1590/1414-462×201700040078

16. Figueira MCS, Silva WP, Silva EM. Integrative literature review: access to primary healthcare services. Rev Bras Enferm. 2018;71(3):1178-1188. doi: 10.1590/0034-7167-2017-0441

17. Lowen IMV, Peres AM, Ros C, Poli NP, Faoro NT. Innovation in nursing health care practice: expansion of access in primary health care. Rev Bras Enferm. 2017;70(5):898-903. doi: 10.1590/0034-7167-2016-0131

18. Sousa ZAA, Silva JG, Ferreira MA. Knowledge and practices of teenagers about health: implications for the lifestyle and self care. Esc Anna Nery. 2014;18(3):400-6. doi: 10.5935/1414-8145.20140057

19. Oliveira ACB. Diferenças e semelhanças entre os sistemas da Civil Law e da Common Law. Constituição, Economia e Desenvolvimento: Rev Acad Bras Dir Const[Internet]. 2014 [cited 2020 Mar 15];6(10):43-68. Available from: http://www.abdconst.com.br/revista11/diferencasAna.pdf

20. Ministério da Saúde (BR). Lei 8080, de 19 de setembro de 1990. Dispõe sobre as condições para a promoção, proteção e recuperação da saúde, a organização e o funcionamento dos serviços correspondentes e da outras providências. Brasília (DF): Diário Oficial da União. 19 set 1990.

21. Veloso RC, Ferreira MA. Health and services: relationships established with users in the light of social representations about citizenship. Rev Enferm UERJ [Internet]. 2013 [cited 2020 Mar 15];21(1):60-5. Available from: https://www.e-publicacoes.uerj.br/index.php/enfermagemuerj/ article/view/6352/5888

22. Shimizu HE, Pamela X, Sanchez MN. Representações Sociais do SUS: Um sistema permeado pela dificuldade de acesso à atenção integral. Tempus - Actas Saúde Colet [Internet]. 2012[cited 2020 Mar 15];6(2):295-306. doi: 10.18569/tempus.v6i3.1170

23. Moura LM, Shimizu HE. Representações sociais de saúde-doença de conselheiros municipais de saúde. Physis. 2017; 27(1):103-25. doi: 10.1590/S0103-73312017000100006

24. Chernicharo IM, Freitas FDS, Ferreira MA. Representações sociais da humanização do cuidado na concepção de usuários hospitalizados. Saude Soc. 2013;22(3):830-9. doi: 10.1590/S0104-12902013000300016

25. Silva RMCRA, Oliveira DC, Pereira ER, Silva MA, Trasmontano PS, Alcantara VCG. Humanization of health consonant to the social representations of professionals and users: a literary study. O Braz J Nurs [Internet]. 2014 [cited 2020 Mar 15];13(4):677-85. Available from: http://www.objnursing.uff.br/index.php/nursing/article/view/4773

26. Silva RN, Freitas FDS, Araújo FP, Ferreira MA. A policy analysis of teamwork as a proposal for healthcare humanization: implications for nursing. Int Nurs Rev. 2016;63(4):572-579. doi: 10.1111/inr.12331

27. France. Ministère des affaires sociales et de la santé. Usagers, votre santé, vos droits. 2014. 148p.

28. Funghetto SS, Silveira SM, Silvino AM, Karnikowsk MGO. Perfil profissional tendo o sus como base das diretrizes curriculares da área da saúde no processo avaliativo. Saúde Redes. 2015;1(3):103-20. doi: 10.18310/2446-4813.2015v1n3p103-120

29. Mota DB, Gomes AMT, Silva ACSS, Ramos RZ, Nogueira VPF, Belém LS. Representações sociais da autonomia do enfermeiro para acadêmicos de enfermagem. Rev Cuid. 2018;9(2):2215-32. doi: 10.15649/cuidarte.v9i2.528

30. Moscovici S. A Psicanálise, sua imagem e seu público. Petropólis. Vozes, 2012. 